\title{
THE EXERCISE OF RELIGIOUS FREEDOM IN EDUCATIONAL INSTITUTIONS IN THE LIGHT OF ECTHR JURISPRUDENCE
}

\author{
REGINA VALUTYTË*, DOVILE் GAILIŪTE்**
}

\section{INTRODUCTION}

Freedom of religion or belief and school education is a multifaceted issue that entails significant opportunities and far-reaching challenges. The school is the most important formal institution for the realization of the right to education. It provides a place of learning, social development and social encounter. At the same time, the school is also a place in which authority is exercised and some individuals, including members of religious or belief minorities, may find themselves in situations of vulnerability. Given this ambivalence of the school environment, safeguards to protect the individual's right to freedom of religion or belief are necessary ${ }^{1}$.

Schools can offer unique possibilities for constructive dialogue among all members of society, and human rights education in particular can contribute to the elimination of negative stereotypes that often adversely affect members of religious minorities. However, freedom of religion or belief and school education has also sparked controversy in many societies, particularly with regard to contentious issues such as religious symbols in the school context and religious instruction ${ }^{2}$.

The role of religious symbols, including wearing religious garments in school and religious education, has been, and continues to be, a matter of controversy in a number of countries. Pupils/students or teachers/professors observing religious dress code, including Islamic headscarves and Sikh turbans, have in some countries been expelled from schools, denied access to higher education, suspended from their jobs or had other rights restricted. Parents and (or) children seeking to benefit from the exemptions from

\footnotetext{
DOI: 10.2478/wrlae-2013-0009

* Associate Professor; Mykolas Romeris University, Faculty of Law, Department of International and European Union Law. Research interests: public international law, European Union institutional law, human rights law.

** Lecturer; Mykolas Romeris University, Faculty of Law, Department of International and European Union Law. Research interests: human rights law, international public law.

1 Rapporteur's Digest on Freedom of Religion or Belief $<$ http://www.ohchr.org/Documents/Issues/Religion/RapporteursDigestFreedomReligionBel ief.pdf $>$ accessed 1 May 2012.

2 ibid.
} 
religious classes are forced to reveal their belief or the fact that they are nonbelievers that raises concerns about the proper implementation of the Article 9 ECHR and Article 2 of Protocol No. 1 of the European Convention on Human rights (hereinafter ECHR or the Convention).

So far, the European Court of Human Rights (hereinafter ECtHR or the Court) has dealt with diverse forms of religious symbols. The relevance of the issue is demonstrated by the new applications raising new issues concerning the display/wearing of religious symbols. And, as the President of the Strasbourg Court Sir Nicolas Bratza indicated: 'this may be far from the Court's last word on the question of the wearing of religious dress or symbols.' ${ }^{3}$

Furthermore, the decisions delivered by the ECtHR against Norway, Turkey and Poland showed that not all Member States of the Council of Europe are ready to ensure education and teaching consistent with parents religious and philosophical convictions. As the legal regulation related to the content of subjects and the curriculum of classes itself is in constant change, the question of educational standards consistent with religious freedom remains acute.

Thus, the main purpose of this article is to discover what criteria are applicable to the content of teaching, i.e. the teaching of religion classes, subjects having religious content and (or) alternative subjects, and to what extent the usage of religious symbols is permitted in educational institutions. To this end, the authors will analyze: 1) the application of Article 9 of the Convention and Article 2 of Protocol 1 of the ECHR in the field at issue; 2) the requirements set for education and teaching consistent with their own religious and philosophical convictions; 3) the extent of the margin of appreciation of states in the prohibition (limitation) on the use of religious symbols.

\section{EDUCATION CONSISTENT WITH RELIGIOUS CONVICTIONS}

The legal regulation and values guiding education in European states have developed in the light of ECtHR's practice in interpreting Article 9 of the ECHR and Article 2 of Protocol No. 1 of the ECHR ${ }^{4}$. As has been mentioned above, in a number of cases the Court reiterated that freedom of thought, conscience and religion, as enshrined in Article 9, entails, inter alia, freedom to hold or not to hold religious beliefs and to practice or not to practice a religion ${ }^{5}$, including the right of individuals not to be required to reveal their faith or religious beliefs and not to be compelled to assume a

\footnotetext{
3 Nicolas Bratza, 'The "Precious Asset": Freedom of Religion under the European Convention on Human Rights' in Mark Hill (ed), Religion and Discrimination Law in the European Union (European Consortium for Church and State Research, 2012) 22.

${ }^{4}$ Article 2 of Protocol No. 1 provides: 'No person shall be denied the right to education. In the exercise of any functions which it assumes in relation to education and to teaching, the State shall respect the right of parents to ensure such education and teaching in conformity with their own religious and philosophical convictions.

${ }^{5}$ Kokkinakis $v$ Greece (1993) Series A no 260-A, para 31; Buscarini and Others $v$ San Marino [GC] ECHR 1999-I, para 34; Grzelak v Poland App no 7710/02 (ECtHR, 15 June 2010), para 85.
} 
stance from which it may be inferred whether or not they have such beliefs ${ }^{6}$. The Court accepted that Article 9 was also a precious asset for nonbelievers: there would be an interference with the negative aspect of this provision when a state brought about a situation in which individuals were obliged - directly or indirectly - to reveal that they are non-believers ${ }^{7}$. This is all the more important when such obligations occur in the context of education, where Article 2 of Protocol No. 1, which is regarded as lex specialis in relation to Article 9 of the ECHR, comes into play ${ }^{8}$.

Under the well-established jurisprudence of the ECtHR, Article 2 of Protocol No. 1 does not permit a distinction to be drawn between religious instruction and other subjects. It enjoins a state to respect parents' convictions, be they religious or philosophical, throughout the entire State education programme ${ }^{9}$. That duty is broad in its extent as it applies not only to the content of education and the manner of its provision but also to the performance of all the 'functions' assumed by a state. The verb 'respect' means more than 'acknowledge' or 'take into account'. The term 'conviction', taken on its own, is not synonymous with the words 'opinions' and 'ideas'. It denotes views that attain a certain level of cogency, seriousness, cohesion and importance ${ }^{10}$.

Furthermore, the Court emphasizes that by binding themselves not to 'deny the right to education', the states guarantee to anyone within their jurisdiction a right of access to educational institutions existing at a given time and the possibility of drawing, by official recognition of the studies which he has completed, profit from the education received ${ }^{11}$. It is in the discharge of a natural duty towards their children - parents being primarily responsible for the 'education and teaching' of their children - that parents may require a state to respect their religious and philosophical convictions. Their right thus corresponds to a responsibility closely linked to the enjoyment and the exercise of the right to education ${ }^{12}$.

However, the setting and planning of the curriculum fall in principle within the competence of the States ${ }^{13}$. In particular, the second sentence of Article 2 of Protocol No. 1 does not prevent States from imparting through teaching or education information or knowledge of a directly or indirectly religious or philosophical kind. It does not even permit parents to object to the integration of such teaching or education in the school curriculum, for otherwise all institutionalized teaching would run the risk of proving impracticable $^{14}$. On the other hand, the second sentence of Article 2 of

${ }^{6}$ Alexandridis $v$ Greece App no 19516/06 (ECtHR, 21 February 2008), para 38; Hasan and Eylem Zengin v Turkey App no 1448/04 (ECtHR, 9 October 2007), para 76; Grzelak (n 5), para 87.

${ }^{7}$ Grzelak (n 5), para 87.

${ }^{8}$ Folgerø and Others $v$ Norway [GC] ECHR 2007-III, para 54; Kjeldsen, Busk Madsen and Pedersen v Denmark (1976) Series A no 23, para 50.

${ }^{9}$ Kjeldsen, Busk Madsen and Pedersen (n 8), para 51.

${ }^{10}$ Valsamis $v$ Greece ECHR 1996-VI, paras 25 and 27; Campbell and Cosans $v$ the United Kingdom (1982) Series A no 48, paras 36-37.

${ }^{11}$ Kjeldsen, Busk Madsen and Pedersen (n 8), para 52.

12 ibid, para 52.

${ }^{13}$ Valsamis (n 10), para 28.

${ }^{14}$ Kjeldsen, Busk Madsen and Pedersen (n 8), para 53. 
Protocol No. 1 implies that a state, in fulfilling the functions assumed by it in regard to education and teaching, must take care that information or knowledge included in the curriculum is conveyed in an objective, critical and pluralistic manner. The State is forbidden to pursue an aim of indoctrination that might be considered as not respecting parents' religious and philosophical convictions ${ }^{15}$.

Due to the guidelines on the implementation of the right to education consistent with religious convictions formulated mainly by the ECtHR, national jurisdictions have faced a number of changes in the legal regulation. Religious education in Europe has been closely tied in with secular education. In most states religious education forms a part of secondary school curriculum, with exemptions provided from religion classes or alternatives provided.

Of the 46 Member States of the Council of Europe, 43 provide religious education classes in state schools. Only Albania, France (with the exception of the Alsace and Moselle regions) and Macedonia are the exceptions to this rule. In Slovenia, non-confessional teaching is offered in the last years of state education ${ }^{16}$. In 25 of the 46 Member States (including Turkey), religious education is a compulsory subject. However, the scope of this obligation varies depending on the State. In five countries, namely Finland, Greece, Norway, Sweden and Turkey, the obligation to attend classes in religious education is absolute. All pupils professing particular religion are obliged to partial or full extent to attend religious classes. However, ten States allow for exemptions under certain conditions. This is the case in Austria, Cyprus, Denmark, Ireland, Iceland, Liechtenstein, Malta, Monaco, San Marino and the United Kingdom. In the majority of these countries, religious education is denominational ${ }^{17}$.

Ten other countries give pupils the opportunity to choose a substitute lesson in place of compulsory religious education. This is the case in Germany, Belgium, Bosnia and Herzegovina, Luxembourg, the Netherlands, Serbia, Slovakia and Switzerland. In those countries, denominational education is included in the curriculum drawn up by the relevant ministries and pupils are obliged to attend unless they have opted for the substitute lesson proposed ${ }^{18}$. In contrast, 21 Member States do not oblige pupils to attend classes in religious education. Religious education is generally authorized in the school system but pupils only attend if they have made a request to that effect. This is the case in the largest group of States: Andorra, Armenia, Azerbaijan, Bulgaria, Croatia, Spain, Estonia, Georgia, Hungary, Italy, Latvia, Moldova, Poland, Portugal, the Czech Republic, Romania, Russia, Ukraine and Lithuania. Finally, in a third group of States, pupils are obliged to attend a religious education or substitute class ${ }^{19}$.

The general overview of religious education in Europe shows that, in spite of the variety of teaching models, almost all Member States offer at least one route by which pupils can opt out of religious education classes (by providing an exemption mechanism or the option of attending a lesson

\footnotetext{
${ }^{15}$ Hasan and Eylem Zengin (n 6), para 71.

16 ibid, para 30.

17 ibid, para 31.

${ }^{18}$ Hasan and Eylem Zengin (n 6), para 32.

19 ibid, para 33.
} 
in a substitute subject, or by giving pupils the choice of whether or not to sign up to a religious studies class ${ }^{20}$. However, the choice itself does not guarantee that the Member States ensure in practice an education consistent with religious convictions in line with the requirements set forth explicitly and implicitly in Article 2 of Protocol No. 1 and Article 9 of the ECHR.

Taking into account the legal regulation existing in the states, there are several situations relevant to the question of education consistent with religious convictions which must be distinguished and analyzed: (a) obligatory instruction in a particular religion or belief or subjects involving religious elements; (b) attending lessons in a substitute subject unrelated to religion; (c) coercive participation in classes of a certain type that, by their nature, have potential for generating discussion, particularly in very religious families.

Obligatory instruction in a particular religion or belief or subjects involving religious elements, such as a course in the general history of religions and ethics, has been discussed before the ECtHR in a number of cases. Interpreting the right to an education consistent with religious convictions, the ECtHR has consistently reiterated that under Article 2 of Protocol No. 1 it remained, in principle, within the national margin of appreciation left to the States to decide whether to provide religious instruction in public schools and, if so, what particular system of instruction had to be adopted ${ }^{21}$. Nevertheless, a state was forbidden to pursue an aim of indoctrination that might be considered as not respecting parents' religious and philosophical convictions ${ }^{22}$.

To examine the compliance of national legal regulations with this aim, the ECtHR has developed a two-step system. First of all, the Court analyzes whether the curriculum is conveyed in an objective, critical and pluralistic manner. Priority being given to knowledge of one religion cannot itself be viewed as a departure from the principles of pluralism and objectivity which would amount to indoctrination, having regard to the fact that, notwithstanding the State's secular nature, a particular religion is the majority religion practiced in the state. It could be considered as remaining within acceptable limits for the purposes of Article 2 of Protocol No. 1 as long as, as has been mentioned, the information or knowledge in the syllabus is disseminated in an objective, critical and pluralist manner ${ }^{23}$.

Secondly, where a state includes religious instruction amounting to indoctrination in the curriculum for study, it is then necessary, insofar as possible, to avoid a situation in which pupils face a conflict between the religious education given by the school and the religious or philosophical convictions of their parents by providing an exemption mechanism or the option of attending a lesson in a substitute subject, or by making attendance at religious studies classes entirely optiona ${ }^{24}$. Recent cases decided before

\footnotetext{
20 ibid, para 34.

${ }^{21}$ Kjeldsen, Busk Madsen and Pedersen (n 8), para 53.

22 ibid, para 53; Hasan and Eylem Zengin (n 6), para 52.

${ }^{23}$ Hasan and Eylem Zengin (n 6), para 71.

24 ibid, para 63; Folgerø and Others (n 8), para 89.
} 
the ECtHR, Folgerø and Others v. Norway ${ }^{25}$ and Hasan and Eylem Zengin v. Turkey ${ }^{26}$, demonstrated a lack of pluralism and objectivity in a religious education and did not avoid the conflict between religious education and the religious convictions of parents.

In the Folgerø and Others case the Court reviewed, under Article 2 of Protocol No. 1, the arrangements for a compulsory subject in Christianity, Religion and Philosophy taught during the ten years of compulsory schooling in Norway. Besides the curriculum of the subject, which was dominated by a preponderance of Christianity, the Court took into account the legal provisions of the 1998 Education Act that aimed at helping to give pupils a Christian and moral upbringing during primary and lower secondary education, and concluded that the course's curriculum failed to comply with the requirements of pluralism and objectivity. Furthermore, the Court went on to analyze whether a partial exemption from the subject ensured consistency between the religious education and the religious convictions of the applicants, coming to the conclusion that it did not. The Court took into account that, first of all, parents could face difficulties in identifying the parts of the teaching that they considered as amounting to the practice of another religion or adherence to another philosophy of life; secondly, the requirement to give reasonable grounds in the request for the exemption created a risk that the parents might feel compelled to disclose intimate aspects of their own religious and philosophical convictions to the school authorities taking a decision; thirdly, the parental note requesting partial exemption did not necessarily mean that the pupil concerned would be exempted from the part of the curriculum ${ }^{27}$.

In the Hasan and Eylem Zengin case the ECtHR concluded that the instruction provided in the school subject 'religious culture and ethics', whose title made it seem neutral, could not be considered to meet the criteria of objectivity and pluralism, nor did it respect the religious and philosophical convictions of the applicant, a follower of the Alevi faith. The Court concluded that the religious diversity which prevailed in Turkish

${ }^{25}$ Folgerø and Others (n 8).

${ }^{26}$ Hasan and Eylem Zengin (n 6).

27 Folgerø and Others ( $\mathrm{n}$ 8), paras 85-100. The view of the court was shared by the scholars. E.g. C. Evans highlights the danger of allowing for sole or predominant focus on the dominant religion. Where there is a religious majority in a state to which most students, parents and teachers belong and where that religion dominates the set curriculum it is quite possible for even well-meaning teachers to begin to blur the line between religious instruction and education about religion. Teachers may well have deeper knowledge about, and greater enthusiasm for, teaching their own religion than other religions or beliefs and a teacher with a deep commitment to a religious position may find it personally challenging to teach it in a neutral and objective manner. Carolyn Evans, 'Religious Education in Public Schools: An International Human Rights Perspective' (2008) 8 Human Rights Law Review 464. However, one should be in mind that the decision was supported by 9 judges out of 17 and, therefore, was the background for separate and dissenting opinions. Two judges of the Grand Chamber submitted a separate opinion stating that the Grand Chamber of the ECtHR had to declare the application inadmissible. Separate opinion of judges Zupančič and Borrego Borrego in case Folgerø and Others. Besides that, eight judges (in contrast to nine who supported the submissions of the applicants) presented a joint dissenting opinion stating that information or knowledge included in the curriculum of the subject was conveyed in an objective, critical and pluralistic manner and there was no violation of Article 2 of Protocol No. 1. Joint dissenting opinion of judges Wildhaber, Lorenzen, Birsan, Kovler, Steiner, Borrego Borrego, Hajiyev and Jebens in case Folgerø and Others. 
society was not taken into account as pupils received no teaching on the confessional or ritual specificities of the Alevi faith, although the proportion of the Turkish population belonging to it is very large. Furthermore, there were no appropriate means to ensure respect for parents' convictions, as only children of Turkish nationality who belonged to the Christian or Jewish religions had the option of exemption, provided they affirmed their adherence to those religions, revealing their religious beliefs and convictions $^{28}$.

The ECtHR's position in this and other cases clearly shows that Turkey and other countries with the same system of virtuous education must either stop making religious classes compulsory (by exemption or giving alternatives) or must ensure that the syllabus treats all belief systems equally. However, in recent discussions in Turkey, experts have expressed the view that the latter is virtually impossible ${ }^{29}$.

The subjects that form a part of virtuous education as an alternative to religious classes, e.g. ethics, have also been the subject of discussions before the ECtHR. In Grzelak v. Poland the applicant complained of the discriminatory nature of the non-provision of courses in ethics and the resultant absence of a mark for 'religion/ethics' on his school reports. The parents of the applicant systematically requested the school authorities to organize classes in ethics for him, as provided for in the Ordinance of the Minister of Education of 13 July 2007. However, no such classes were organized for the applicant throughout his entire schooling at primary and secondary level due to the lack of sufficient numbers of pupils interested in attending such a class.

The Court took the view that the provisions of the Ordinance of the Minister of Education of 13 July 2007, which provided for a mark to be given for 'religion/ethics' on school reports could not, as such, be considered to infringe Article 14 taken in conjunction with Article 9 of the Convention as long as the mark constituted neutral information on the fact that a pupil had followed one of the optional courses offered at a school. However, the ECtHR decided that a regulation of this kind had also to respect the right of pupils not to be compelled, even indirectly, to reveal their religious beliefs or lack thereof and found that the absence of a mark for 'religion/ethics' would be understood by any reasonable person as an indication that the pupil did not follow religious education classes, which were widely available, and that he was thus likely to be regarded as a person without religious beliefs. In the Court's view, the fact of having no mark for 'religion/ethics' inevitably had a specific connotation and distinguished the persons concerned from those who had a mark for the subject ${ }^{30}$.

Interestingly, the Constitutional Court of Poland analyzed the constitutionality of the Ordinance and dismissed the arguments concerning the risk of a division between believers and non-believers. The

${ }^{28}$ Hasan and Eylem Zengin (n 6), paras 73-74.

29 Erhan Üstündag, 'ECHR: Compulsory Religious Education Violates Rights' $<$ http://www.bianet.org/english/english/102221-echr-compulsory-religious-educationviolates-rights> accessed 10 May 2012.

${ }^{30}$ Grzelak (n 5), para 94. 
Constitutional Court's judgment was based on the assumption that any interested pupil would be able to follow a class in either of the two subjects concerned, and consequently there would always be a mark on the school report for 'religion/ethics'. However, the ECtHR noticed that the Constitutional Court had overlooked the situation in which a pupil had no mark for 'religion/ethics' on his/her school reports because the schools could not organize ethics classes despite repeated requests from his/her parents $^{31}$.

The situation could become even more problematic if participation in 'religion/ethics' classes are graded, and marks obtained for religious education class or ethics are included in the calculation of a grade point average. The aforementioned Ordinance of the Polish Minister of Education introduced a rule that marks received in religious education class or ethics would be included in the calculation of the average grade obtained by a pupil in a given school year and at the end of a given level of schooling.

This situation has already been examined by the ECtHR, which observed that the above rule might have a real adverse impact on the situation of pupils who could not, despite their wishes, attend a course in ethics. Such pupils would either find it more difficult to raise their grade point average as they could not attend the desired optional subject, or might feel pressured to attend a religion class against their conscience in order to improve their average ${ }^{32}$.

Several scholars and practitioners expressed the view that in the Grzelak case the Court departed from its practice in similar cases, e.g. Saniewski v. Poland in which a complaint in similar situation had been declared manifestly ill-founded. In the Court's view, there were at least three grounds that distinguished the Grzelak case from the Saniewski case. Firstly, differently from Saniewski, in the Grzelak case the allegations concerned all the consecutive school reports of the applicant, including his leaving certificate for primary and lower secondary schools. Secondly, in the present case the Court examined the issues raised in the light of Article 14 taken in conjunction with Article 9. Thirdly, the relevant new factor for the Court was the amended Ordinance of the Minister of Education of 13 July $2007^{33}$. Dissenting with the findings of the Court, Judge D. Thór Björgvinsson expressed the view that quantitative differences in the facts of the case cannot render the reasoning in the Saniewski case irrelevant to the facts of the Grzelak case. He could not support the view that the facts of the Grzelak case were different from those in the Saniewski case merely in that the impugned school reports covered all of the third applicant's primary and secondary schooling, whereas in the Saniewski case only one report had been at issue ${ }^{34}$. In supporting this position, Judge A. Buyse noticed that it seemed rather odd that the Court after nine years simply took a different

\footnotetext{
31 ibid, para 95.

${ }^{32}$ Grzelak (n 5), para 95. It is noteworthy in this respect that the Constitutional Court of Poland in its judgment of 2 December 2009 referred to the risk that the choice of religion as an optional subject could have been the result of pressure from local public opinion, but nevertheless did not address this issue as lying outside its jurisdiction.

${ }^{33}$ Grzelak (n 5), para 98.

${ }^{34}$ Partly dissenting opinion of Judge David Thór Björgvinsson in case Grzelak (n 5), para 8 (vii).
} 
$\operatorname{position}^{35}$.

Another example is the recent Appel-Irrgang case concerning mandatory ethics classes for pupils in grades 7 to 10 , which the applicants considered to be contrary to their Protestant belief. Regarding the applicants' claims that the ethics classes were not neutral, the Court observed that the relevant provisions of the Berlin School Act, which envisaged the requirement that the ethics classes' aim was to examine fundamental questions of ethics independently of pupils' cultural, ethnic and religious origins, meant that the classes were therefore in conformity with the principles of pluralism and objectiveness established by Article 2 of Protocol No. 1. Addressing the applicants' complaint that, despite the Christian tradition of Germany, the Christian religion was not adequately represented in the ethics course, the Court noted that it fell within a State's margin of discretion to decide whether or not a school curriculum was, in view of the country's tradition, to dedicate more attention to a particular religion and whether ethics should be taught in separate classes. As regards the applicants' claims that the ethics course was contrary to their religious beliefs, the Court observed that neither the School Act nor the curriculum gave priority to one particular belief; moreover, nothing impeded the first applicant from continuing to attend the Protestant religion course offered by the school ${ }^{36}$.

The third group of cases and activities are related to compulsory participation in classes of a certain type that, by their nature, have the potential for discussion, e.g. sexual education. In essence, these cases do not differ in argumentation from the cases concerning attendance at alternatives to religious classes, where the ECtHR employs the test of objectiveness and emphasizes the margin of appreciation enjoyed by the states in construction of the school curriculum.

Kjeldsen, Busk Madsen and Pedersen v. Denmark, which concerned the conscientious objection to sex education in school, was one of the first cases to be dealt before the ECtHR with reference to Article 2 Protocol No. 1. In deciding the case in favor of the respondent government the Court proposed a restrictive interpretation of parents' rights with regard to the religious and philosophical orientation of their children's education ${ }^{37}$. The ECtHR concluded that attempts to warn pupils against phenomena the state viewed as disturbing, for example, the excessive frequency of births out of wedlock, induced abortions and venereal diseases, were very general in character and did not entail an overstepping of the bounds of what a democratic State might regard as in the public interest. In the Court's opinion the legislation in dispute did not attempt at indoctrination aimed at advocating a specific kind of sexual behavior and thus could not offend the applicants' religious and philosophical convictions ${ }^{38}$.A recent complaint in

35 Antoine Buyse, 'Judgment on Non-Religious Education in Poland' $<$ http://echrblog.blogspot.com/2010/06/judgment-on-non-religious-education-in.html> accessed 10 May 2012.

${ }^{36}$ Appel-Irrgang and Others v Germany (dec.) App no 45216/07 (ECtHR, 6 October 2009).

37 Javier Martínez-Torrón, 'The (Un)protection of Individual Religious Identity in the Strasbourg Case Law' (2012) 1 Oxford Journal of Law and Religion 1.

${ }^{38}$ Kjeldsen, Busk Madsen and Pedersen (n 8), paras 54-55. 
the Dojan and other v. Germany case was also rejected as manifestly illfounded as there was no indication that the classes and activities at issue had put into question the parents' sexual education of their children based on their religious convictions. Neither had the school authorities manifested a preference for a particular religion or belief within those activities. The sex education classes, from which the applicants had requested exemption for their children, had aimed at the neutral transmission of knowledge about procreation, contraception, pregnancy and childbirth, based on current scientific and educational standards. The goal of the theatre workshop had been to raise awareness of sexual abuse of children with a view to its prevention. The carnival celebrations had not been accompanied by any religious activities and the possibility of attending alternative activities had aimed to accommodate the moral and religious convictions of children and parents belonging to the Christian Evangelical Baptist community as far as possible. The Court underlined that the Convention did not guarantee the right not to be confronted with opinions that were opposed to one's own convictions. The applicants had furthermore been free to educate their children after school and at weekends in conformity with their religious convictions ${ }^{39}$.

To conclude, the ECtHR's findings in the Folgerø, Hasan and Eylem Zengin and Grzelak cases demonstrate that in practice states do not always comply with the requirement to ensure education consistent with religious convictions set forth in Article 9 and Article 2 of Protocol 1 ECHR. The curriculum of obligatory religious subjects is not always conveyed in an objective, critical and pluralistic manner and states fail to ensure that existing mechanisms of exemption and (or) alternative teaching do not oblige a person to reveal his/her belief or the fact that he is a non-believer, or that he/she does not appear in a position from which it may inferred whether or not he/she has such beliefs.

\section{DISPLAY OF RELIGIOUS SYMBOLS IN EDUCATIONAL INSTITUTIONS}

In 2010 the research department of BBVA, Spain's second-largest bank, carried out a study on issues regarding religious symbols in schools ${ }^{40}$. According to the study, $52.6 \%$ of those polled in 12 European Union Member States were 'opposed' or 'totally opposed' to the use of the religious garment in schools. More than $80 \%$ of Bulgarian and $65 \%$ of French respondents said they were opposed to veils. Opposition was lowest in Poland with only $25.6 \%$ against, followed by Denmark with $28.1 \%$ opposed. In contrast, $54.4 \%$ of those polled were in favour of classrooms displaying crucifixes. In Spain and Italy, two nations with a strong Roman Catholic tradition, support for the display of crucifixes in classrooms stood

\footnotetext{
${ }^{39}$ Dojan and Others $v$ Germany (dec.) App no 319/08 (ECtHR, 13 September 2011).

40 The researchers polled 1,500 people in 12 EU Member States - Belgium, Britain, Bulgaria, Denmark, France, Germany, Greece, Italy, Poland, Portugal, Spain and Sweden — as well as in Switzerland and Turkey.
} 
at $69.9 \%$ and $49.3 \%$ respectively. Support for the display of crucifixes in classrooms shot up to $77 \%$ in Britain and $78.8 \%$ in Denmark ${ }^{41}$.

A comparative analysis of the legal aspects reveals a set of regulations or prohibitions on wearing religious symbols in more than 25 countries all over the world ${ }^{42}$. There are different levels of regulation or prohibition on the wearing of religious symbols including constitutional provisions, legislative acts at the national level, regulations and mandatory directives of regional or local authorities, rules in public or private organizations or institutions (e.g. school rules) and court judgments ${ }^{43}$.

For more than twenty years the place of the Islamic headscarf in State education has been the subject of debate across Europe ${ }^{44}$. In most European countries, the debate has focused mainly on primary and secondary schools. However, in Turkey, Azerbaijan and Albania it has concerned not just the question of individual liberty, but also the political meaning of the Islamic headscarf. These are the only Member States of the Council of Europe to have introduced regulations on wearing the Islamic headscarf in universities ${ }^{45}$. Such strict regulation has influenced the volume of applications lodged with the Strasbourg Court against Turkey.

It should be mentioned that the European Commission of Human Rights in its early case-law had decided that the requirement of submitting a photograph without headscarf to obtain a university certificate did not raise an issue under the freedom of religion enshrined in Article 9 of the Convention. The Commission dismissed the applications of Karanduman ${ }^{46}$ and $\mathrm{Bulut}^{47}$ on the grounds that the fact a secular university has regulations on students' dress and that its administrative services are subject to compliance with those regulations does not constitute an interference with the right to freedom of religion and belief.

In contrast, the ECtHR in subsequent case-law departed from the earlier assessments of the Commission and qualified the wearing of headscarves as a religious practice protected by Article 9 of the Convention.

\footnotetext{
41 Estudio $\quad$ Fundación BBVA Mindset $<$ http://www.elpais.com/elpaismedia/ultimahora/media/201004/27/sociedad/20100427elpep usoc_1_Pes_PDF.pdf $>$ accessed 12 March 2012.

${ }^{42}$ More on the display of religious symbols in the different countries see Dovile Gailiute 'Display of Religious Symbols' in D Vitkauskaite-Meurice, R Valutyte and D Gailiute, Limitations to the Freedom of Religion in Democratic Society, Research study (Vilnius: Mykolas Romeris University 2012) 99-122.

43 Report of the Special Rapporteur on freedom of religion or belief, Asma Jahangir. E/CN.4/2006/5, 9 January 2006. para 37.

44 See, eg: Natalie Melmore, 'New Trends in Religious Freedom: The Battle of the Headscarf' (2012) 1 Plymouth Law and Criminal Justice Review 96; Hege Skjeie, 'Headscarves in Schools: European Comparisons' in LMP Loenen and JE Goldschmidt (eds), Religious Pluralism and Human Rights in Europe: Where to Draw the Line? (Intersentia 2007) 129-145; Carolyn Evans, 'The 'Islamic Scarf' in the European Court of Human Rights' (2006) 7 Melbourne Journal of International Law 52.

${ }^{45}$ Leyla Şahin v Turkey [GC] ECHR 2005-XI, para 55.

${ }^{46}$ Karanduman v Turkey App no 16278/90 (Commission Decision, 3 May 1993).

${ }^{47}$ Bulut v Turkey App no 18783/91 (Commission Decision, 3 May 1993).
} 
One of the best-known cases regarding the issue of headscarves in educational institutions is the case of Leyla Sahin v. Turkey ${ }^{48}$. Coming from a traditional family of practicing Muslims, Ms Şahin considered it her religious duty to wear the Islamic headscarf. She was a fifth-year student at the faculty of medicine of Istanbul University when the university authorities issued a circular declaring that students with beards and students wearing the Islamic headscarf would be refused admission to lectures, courses and tutorials ${ }^{49}$. Since Ms Şahin continued wearing the Islamic headscarf, she was refused access to the exam and the course; subsequently she was suspended from the university and pursued her studies in Austria.

Ms Şahin lodged an application with the ECtHR, complaining under Article 9 that she had been prohibited from wearing the Islamic headscarf at her university. The Grand Chamber proceeded on the assumption that the circular in issue, which set forth restrictions of place and manner on the right to wear the Islamic headscarf at universities, constituted an interference with the applicant's right to manifest her religion. However, the Court considered that the impugned interference primarily pursued the legitimate aims of protecting the rights and freedoms of others and of protecting public order. The ECtHR held that there was a legal basis in Turkish law for the interference with Ms Şahin's right to manifest her religion, as the Turkish Constitutional Court had ruled before that wearing a headscarf at universities was in contravention of to the Constitution ${ }^{50}$. As to whether the interference was necessary, the Court noted that it was based in particular on the principles of secularism and equality. The Court considered that, 'when examining the question of the Islamic headscarf in the Turkish context, there had to be borne in mind the impact which wearing such a symbol, which was presented or perceived as a compulsory religious duty, may have on those who chose not to wear it. ${ }^{51}$ The Court did not lose sight of the fact that there were extremist political movements in Turkey, which sought to impose on society as a whole their religious symbols and conception of a society founded on religious precepts ${ }^{52}$. Finally, the Court concluded that, having regard to the Contracting States' margin of appreciation, the interference in issue was justified in principle and proportionate to the aims pursued, and could therefore be considered to have been 'necessary in a democratic society'. It therefore found no violation of Article 9.

The judgment of the Grand Chamber was widely discussed and criticized $^{53}$. Judge Tulkens in her dissenting opinion disagreed with the

\footnotetext{
48 More on the case see: Nathwani Niraj Nathwani, 'Islamic Headscarves and Human Rights: a Critical Analysis of the Relevant Case Law of the European Court of Human Rights' (2007) 25 Netherlands Quarterly of Human Rights 221; Nicholas Gibson, 'An Unwelcome Trend: Religious Dress and Human Rights Following Leyla Şahin vs Turkey' (2007) 25 Netherlands Quarterly of Human Rights 599; Jeremy Gunn, 'Fearful Symbols: The Islamic Headscarf and the European Court of Human Rights in Sahin v Turkey' (20062007) 2 Annuaire Droit et Religions 639.

${ }^{49}$ Leyla Şahin (n 45), para 16.

50 ibid, para 116.

51 ibid, para 115 .

52 ibid

${ }^{53}$ See: Isabelle Rorive, 'Religious Symbols in the Public Space: In Search of a European Answer' (2008-2009) 30 Cardozo Law Review 2669; Nathwani (n 48); Gibson (n 48); Gunn (n 48).
} 
manner in which the principles of secularism and equality were applied and to the way they were interpreted in relation to the practice of wearing the headscarf $\mathrm{f}^{54}$. Judge Tulkens criticized that firstly, the judgment does not address the applicant's argument - which the Government did not dispute that she had no intention of calling the principle of secularism, a principle with which she agreed, into question. Secondly, there is no evidence to show that the applicant, through her attitude, conduct or acts, contravened that principle. Lastly, the judgment makes no distinction between teachers and students (see the case of Dahlab). Regarding the principle of equality, Tulkens ponders as to whether there is a connection between the ban on wearing the headscarf and sexual equality ${ }^{55}$. Moreover, the majority of the Court did not even consider that excluding an adult woman from university was a peculiar path to achieving gender equality ${ }^{56}$.

In all subsequent cases concerning the wearing of religious signs by students or teachers in public schools the Court used the same approach and reasoning as in the case of Leyla Şahin. For instance, in the case of Köse and 93 others $v$. Turkey ${ }^{57}$ the ECtHR justified the ban on wearing Islamic headscarves at school. The Court found that the obligation imposed on pupils to wear a school uniform and not to cover their heads at school is a general rule applicable to all pupils irrespective of their religious beliefs. Consequently, even assuming that the applicants' right to manifest their religion has been interfered with, the Court found no appearance of a violation of Article 9 of the Convention.

It should be mentioned that restrictions concerning the wearing of Islamic headscarves in public education institutions were applicable not only to students, but to teachers as well. For instance, in the case of Kurtulmus v. Turkey ${ }^{58}$ an associate professor at the Faculty of Economics of the University of Istanbul was deemed to have resigned from her post on the grounds that she had wilfully failed to comply with the Rules on Dress applicable to Staff in State Institutions, which prohibited female members of staff from wearing the headscarf when performing their duties in educational institutions. The applicant submitted that the ban on her wearing a headscarf when teaching had violated her right guaranteed by Article 9 of the Convention to manifest her religion freely. The Court noted that the rules on dress apply equally to all public servants, irrespective of their functions or religious beliefs. Considering that public servants act as representatives of the State when they perform their duties, the rules require their appearance to be neutral in order to preserve the principle of secularism and its corollary, the principle of a neutral public service. On this subject, the Court referred to the case of $\operatorname{Vog} t^{59}$ noting that a democratic State may be entitled to require public servants to be loyal to the constitutional principles on which it was founded (as mentioned above,

\footnotetext{
${ }^{54}$ Leyla Şahin (n 45), Dissenting opinion of Judge Tulkens.

55 ibid

${ }^{56}$ Rorive (n 53) 2684.

${ }^{57}$ Köse and 93 Others $v$ Turkey (dec.) App no 26625/02 (ECtHR, 24 January 2006).

${ }^{58}$ Kurtulmuş $v$ Turkey (dec.) App no 65500/01 (ECtHR, 24 January 2006).

${ }^{59}$ Vogt $v$ Germany [GC] (1995) Series A no 323, para 59.
} 
secularism is one of Turkey's constitutional principles). The Court also took into account the margin of appreciation that had to be left to the States in determining the obligations on teachers in the State education system depending on the level of education concerned. Consequently, the Court found that the impugned interference was justified in principle and proportionate to the aim pursued, and declared the application inadmissible. All other applications against Turkey ${ }^{60}$ regarding the wearing of headscarves when performing duties in educational institutions were declared inadmissible.

In the case of Dahlab v. Switzerland ${ }^{61}$ the application was declared inadmissible as well, but the reasoning of the Court was different. The applicant, a primary school teacher who had converted to Islam, complained of the school authorities' decision to prohibit her from wearing a headscarf while teaching. She had previously worn a headscarf in school for a few years without causing any obvious disturbance. The Court declared the application inadmissible, holding that the measure had not been unreasonable and 'necessary in a democratic society'. The Court accepted that it is very difficult to assess the impact that a 'powerful external symbol' such as the wearing of a headscarf may have on the freedom of conscience and religion of very young children (the pupils were aged between four and eight). The Court admitted that it cannot be denied outright that the wearing of a headscarf might have some kind of 'proselytizing effect'. The Strasbourg Court noted that 'it therefore appears difficult to reconcile the wearing of an Islamic headscarf with the message of tolerance, respect for others and, above all, equality and non-discrimination that all teachers in a democratic society must convey to their pupils. ${ }^{62}$ Accordingly, weighing the right of a teacher to manifest her religion against the need to protect pupils by preserving religious harmony, the Court considered that, in the circumstances of the case and having regard, above all, to the tender age of the children, the authorities did not exceed their margin of appreciation.

France's conception of secularism is the most rigidly defined, with strictly enforced policies that keep religion out of the public sphere ${ }^{63}$. Despite massive protests across the country in 2004 the French National Assembly passed the Law on Secularity and Conspicuous Religious Symbols in Schools. The law forbids pupils to wear any religious symbol in public primary (from 11 to 15 y.o.) and secondary schools (from 15 to 18 y.o.). The ban does not concern private schools and universities. The law prohibits public school employees and students from wearing conspicuous religious symbols, including the Islamic headscarf, Jewish skullcap, Sikh

${ }^{60}$ Çağlayan v Turkey (dec.) App no 1638/04 (ECtHR, 3 April 2007); Yılmaz v Turkey (dec.) App no 37829/05 (ECtHR 3 April 2007); Karaduman v Turkey (dec.) App no 41296/04 (ECtHR, 3 April 2007); Tandoğan v Turkey (dec.) App no 41298/04 (ECtHR, 3 April 2007).

${ }^{61}$ Dahlab v Switzerland (dec.) App no 42393/98 ECHR (ECtHR, 15 February 2001).

62 ibid.

${ }^{63}$ See, eg: Susanna Mancini, 'The Power of Symbols and Symbols as Power: Secularism and Religion as Guarantors of Cultural Convergence' (2008-2009) 30 Cardozo Law Review 2629; Gulce Tarhan, 'Roots of the Headscarf Debate: Laicism and Secularism in France and Turkey' (2011) 4 Journal of Political Inquiry $1<$ http://jpi-nyu.org/wpcontent/uploads/2011/02/Roots-of-the-Headscarf-Debate-Laicism-and-Secularism-inFrance-and-Turkey.pdf $>$ accessed 19 March 2012. 
turban, and large Christian crosses. However, the Law does not prohibit more discreet symbols, such as necklaces with a cross, Star of David, or hand of Fatima. In order to enforce the law, the Minister of Education issued a circular specifying practical examples of 'conspicuous' symbols. The law and circular gave headmasters the power to decide whether particular attire was or was not acceptable, allowing them to refer to the 2004 law $^{64}$.

The law has caused outrage and prompted students and their parents to apply to the domestic courts, as well as to lodge applications with the Strasbourg Court. It should be mentioned that the applications submitted concerned not only Islamic headscarves, but Sikh turbans as well. The 2004 Law has often been referred to as the anti-Islamic veil Act, but the applications lodged demonstrate that the Law bans the wearing of any and all conspicuous religious symbols in public schools. After implementation, this policy was the subject of several applications against France lodged with the Strasbourg Court. In the cases of Dogru ${ }^{65}$ and Kervanci $^{66}$ the applicants, both Muslims, were expelled from school for refusal to remove their headscarves during physical education classes despite repeated requests to do so and for breaching the duty of assiduity by failing to participate actively in those classes. The Court found no violation of Article 9 in both cases, holding in particular that the conclusion reached by the national authorities that the wearing of a veil, such as the Islamic headscarf, was incompatible with sports classes for reasons of health or safety was not unreasonable. It accepted that the penalty imposed was the consequence of the refusal of the applicants to comply with the rules applicable on the school's premises - of which they had been properly informed - and not of their religious convictions, as they alleged.

In 2008, six pupils lodged applications concerning their expulsion from school for wearing conspicuous symbols of religious affiliation. Four Muslim girls, ${ }^{67}$ who were wearing a headscarf or kerchief, and two boys, ${ }^{68}$ who were wearing a 'keski', an under-turban worn by Sikhs, were expelled from school for failure to comply with the Education Code, as they refused to remove the offending headwear. In these cases the ECtHR indirectly assessed the Law on Secularity and Conspicuous Religious Symbols in Schools. The Court declared the applications inadmissible, holding in particular that the interference with the pupils' freedom to manifest their religion was prescribed by law and pursued the legitimate aims of protecting the rights and freedoms of others and of public order. As to the punishment of definitive expulsion, it was not disproportionate to the aims pursued as the pupils still had the possibility of continuing their schooling by correspondence courses.

$64 \quad$ VEIL-project. Executive summary: France

$<$ http://www.univie.ac.at/veil/Home3/index.php?id=7,52,0,0,1,0> accessed 19 March 2012.

${ }^{65}$ Dogru v France App no 27058/05 (ECtHR, 4 December 2008).

${ }^{66}$ Kervanci v France App no 31645/04 (ECtHR, 4 December 2008).

${ }^{67}$ Aktas $v$ France (dec.) App no 43563/08 (ECtHR, 30 June 2009); Bayrak v France (dec.) App no 14308/08 (ECtHR, 30 June 2009); Gamaleddyn v France (dec.) App no 18527/08 (ECtHR, 30 June 2009); Ghazal v France (dec.) App no 29134/08 (ECtHR, 30 June 2009).

68 Jasvir Singh v France (dec.) App no 25463/08 (ECtHR, 30 June 2009); Ranjit Singh v France (dec.) App no 27561/08 (ECtHR, 30 June 2009). 
Aside from Islamic headscarf issues, in its jurisprudence the ECtHR has had to deal with the problem of the display of other religious symbols in public educational institutions. For instance, in 2006, Ms Lautsi lodged an application ${ }^{69}$ regarding display of the crucifix in public school classrooms ${ }^{70}$. Ms Lautsi's children attended a state school where all the classrooms had a crucifix on the wall, which she considered contrary to the principle of secularism by which she wished to bring up her children. Following a decision of the school's governors to keep religious symbols in classrooms, Ms Lautsi brought administrative proceedings and complained in particular, without success, of an infringement of the principle of secularism. She complained before the Court that the display of the crucifix in the State school attended by her children was in breach of Article 9 and of Article 2 of Protocol No. 1.

The ECtHR Chamber acknowledged the crucifix was a 'powerful external symbol' ${ }^{17}$ and held that the display of such symbols in the classrooms "may be emotionally disturbing for pupils of other religions or those who profess no religion.' 72 The Court considered that the compulsory display of a symbol of a particular faith in classrooms restricts the right of parents to educate their children in conformity with their convictions, and the right of schoolchildren to believe or not believe. Such restrictions are incompatible with the State's duty to respect neutrality in the exercise of public authority, particularly in the field of education.

The judgment of the Chamber was met with strong indignation and the Government of Italy asked for the case to be referred to the Grand Chamber. Several European Council Member States $^{73}$, including Lithuania $^{74}$, intervened as third parties and submitted written briefs.

The Grand Chamber concluded that the decision whether crucifixes should be present in State school classrooms is, in principle, a matter falling within the margin of appreciation of the respondent State. Moreover, the fact that there is no European consensus on the question of the presence of religious symbols in State schools speaks in favour of that approach. Furthermore, a crucifix on a wall is an essentially passive symbol, a of importance in the Court's view, particularly having regard to the principle of neutrality. It cannot be deemed to have an influence on pupils comparable to that of didactic speech or participation in religious activities ${ }^{75}$. The Court also underlined that the presence of crucifixes is not associated with compulsory teaching about Christianity and that Italy opens up the school environment in parallel to other religions (it was not forbidden for pupils to wear Islamic headscarves or other symbols or apparel having a religious connotation; alternative arrangements were possible to help schooling fit in

\footnotetext{
${ }^{69}$ Lautsi and Others $v$ Italy [GC] ECHR 2011 (extracts).

${ }^{70}$ For more on the case, see: Carlo Panara, 'Lautsi $v$ Italy: The Display of Religious Symbols by the State' (2011) 17 European Public Law 139.

${ }^{71}$ Lautsi and Others $v$ Italy App no 30814/06 (ECtHR, 3 November 2009), para 54.

72 ibid, para 55.

${ }^{73}$ Armenia, Bulgaria, Cyprus, the Russian Federation, Greece, Lithuania, Malta, Monaco, Romania and the Republic of San Marino.

${ }^{74}$ Lithuania paid attention to the margin of appreciation given to the states to choose the ways for the implementation of rights and freedoms guaranteed by the Convention, and in the present case - the ways of implementing a principle of secularism.

${ }^{75}$ Folgerø and Others (n 8), para 94; Hasan and Eylem Zengin (n 6), para 64.
} 
with non-majority religious practices, etc.). Finally, the Court observed that the applicant retained in full her right as a parent to enlighten and advise her children, to exercise in their regard her natural functions as educator and to guide them on a path in line with her own philosophical convictions. In its Grand Chamber judgment, the Court found no violation of Article 2 of Protocol No. 1, and it held that no separate issue arose under Article $9^{76}$, which led certain authors to conclude that that 'Islam was not compatible with the values of the Convention'77.

The jurisprudence of the Strasbourg Court raised a discussion about 'double standards' applicable to different religions. In all cases regarding the wearing of Islamic headscarves in public educational institutions, the ECtHR justified the bans applied by a state on the grounds of the margin of appreciation and the principles of secularism and neutrality of the educational institutions. However in the Crucifix case, the Court did not impose such an important role to the principle of secularism.

\section{CONCLUSIONS}

1. Although the majority of Member States of the Council of Europe still provide religious education classes in state schools, most of them offer exemption mechanisms or lessons in substitute subjects, or give pupils the choice of whether or not to sign up to a religious studies class in order to comply with the prohibition on indoctrination. However, the ECtHR's decisions in the Folgerø, Hasan and Eylem Zengin and Grzelak cases indicate that the legal mechanisms for opting out of confessional religious instruction or substitute subjects in place of compulsory religious education themselves do not guarantee that states in practice ensure that the information and knowledge in the curriculum is conveyed in an objective, critical and pluralistic manner, and that the individuals seeking to benefit from the exemptions or alternatives are not obliged to reveal their belief or the fact that they are non-believers, and do not find themselves in a position from which it may be inferred whether or not they have such beliefs.

2. The jurisprudence of the Strasbourg Court in respect of the display of religious symbols in educational institutions raised a discussion about 'double standards' applicable to Islam and Christianity. In all cases regarding the wearing in public educational institutions of an Islamic headscarf, which was qualified by the Court as 'powerful external symbol', the ECtHR justified the bans applied by States on the grounds of the margin of appreciation and the principles of secularism and neutrality of educational institutions. However, in the Lautsi case, the Court did not ascribe such an important role to the principle of secularism and concentrated on the proportionality of the limitation. Due to the essentially passive nature of the symbol and the tolerance of Italy towards the use of the symbols of other religions or beliefs, the Court also approved the

\footnotetext{
${ }^{76}$ Lautsi v Italy (n 69).

${ }^{77}$ Ukri Soirila, 'The European Court of Human Rights, Islam and Foucauldian Biopower' (2011) 2 Helsinki Law Review 368.
} 
exposure of a crucifix as a matter falling within the margin of appreciation of the state. 